\title{
Pengaruh Model Pembelajaran Somatic Auditory Visualization Intellectualy berbantuan Lingkungan Hidup terhadap Hasil Belajar IPA Siswa
}

\author{
Kadek Andre Indrawan ${ }^{1 *}$, M.G. Rini Kristiantari ${ }^{2}$, I Gusti Agung Oka Negara ${ }^{3}$ \\ 123Jurusan Pendidikan Guru Sekolah Dasar (PGSD), Universitas Pendidikan Ganesha, Singaraja, Indonesia.
}

\author{
A R T I C L E I N F O \\ Article history: \\ Received 20 Desember \\ 2017 \\ Received in revised form \\ 6 januari 2018 \\ Accepted 19 Januari 2018 \\ Available online 25 \\ Februari 2018 \\ Kata Kunci: \\ SAVI, Lingkungan Hidup, \\ Hasil Belajar IPA \\ Keywords: \\ SAVI, Environment, Science \\ Results Learning
}

\begin{abstract}
A B S T R A K
Penelitian ini bertujuan untuk mengetahui perbedaan yang signifikanterhadap hasil belajar IPA antara siswakelas IV SD Gugus Ir. Soekarno Denpasar Selatan tahun pelajaran 2016/2017 yang dibelajarkan dengan menggunakan model pembelajaran SAVI berbantuan lingkungan hidup dan siswa kelas IV SD Gugus Ir. Soekarno Denpasar Selatan tahun pelajaran 2016/2017 yang dibelajarkan dengan pembelajaran konvensional. Jenis penelitian ini ialah quasi eksperiment (eksperimen semu). Disain yang digunakan adalah desain Nonequivalent Control Group Desigh. Populasi dari penelitian ini adalah seluruh siswa kelas IV SD Gugus Ir. Soekarno Denpasar Selatan yang berjumlah 329 siswa. Data hasil belajar IPA siswa diperoleh melalui tes, tes yang digunakan adalah tes pilihan ganda biasa, setelah diperolehnya data hasil belajar IPA siswa selanjutnya dianalisis dengan uji-t. Berdasarkan taraf signifikan $5 \%$ dan $\mathrm{dk}=74(\mathrm{n} 1+\mathrm{n} 2-2=37+39-2=74)$ di peroleh tabel sebesar 2,00 sedangkan thitung 3,49 (thitung $=3.49>t_{\text {tabel }}=2.00$ ). Nilai rata - rata siswa kelas eksperimen sebesar 74,05 dan siswa kelas kontrol sebesar 67,48. Dengan demikian, terdapat perbedaan yang signifikan terhadaphasil belajar IPA antara siswa kelas IV SD Gugus Ir. Soekarno Denpasar Selatan tahun pelajaran 2016/2017yang dibelajarkan dengan model pembelajaran SAVI berbantuan lingkungan hidup dan siswa kelas IV SD Gugus Ir. Soekarno Denpasar Selatan tahun pelajaran 2016/2017 yang dibelajarkan dengan pembelajaran konvensional.
\end{abstract}

A B S T R A C T

This study aims to determine the significant difference to the results of science learning between fourth graders Elementary School Gugus Ir. Soekarno South Denpasar academic year 2016/2017 which was taught by using SAVI model of assisted living environment and fourth grade students of SD Gugus Ir. Soekarno South Denpasar academic year 2016/2017 which was taught by conventional learning. This type of research is quasi experiment (quasi experiment).. Student learning outcomes data obtained through the test, the test used is the usual double-choice test, after obtaining the data of students' science learning outcomes then analyzed by t-test. Based on the significant level of $5 \%$ and $\mathrm{dk}=74(\mathrm{n} 1+\mathrm{n} 2-2=37+39-2=74)$ obtained by ttable of 2.00 while tcount 3.49 (tcount $=$ $3.49>$ ttable $=2.00$ ). The average grade of the experimental class is 74.05 and the control class is 67.48. Thus, there is a significant difference to the results of science learning between fourth graders Elementary School Gugus Ir. Soekarno South Denpasar academic year 2016/2017 which was taught by SAVI model of environment-assisted learning and fourth grade students of SD Gugus Ir. Soekarno South Denpasar academic year 2016/2017 which was taught by conventional learning.

\footnotetext{
1 Corresponding author.

E-mail addresses: andreindrawan857@gmail.com (Kadek Andre Indrawan)
} 


\section{Pendahuluan}

Guru merupakan salah satu komponen yang sangat berperan penting dalam terselenggaranya proses pendidikan. Keberadaan guru merupakan pelaku utama dalam menentukan berhasil tidaknya proses pembelajaran yang diterapkan. Pembelajaran dikatakan berhasil jika siswa mendapatkan hasil belajar sesuai atau melebih nilai rata-rata yang sudah ditetapkan. Agar pembelajaran berhasil guru haruslah pintar atau pandai dalam mendesain suatu pembelajaran seefektif mungkin agar pembelajaran menjadi bermakna dimana siswa lebih memahamai materi yang diajarkan dan tentunya berpengaruh pada hasil belajar siswa. Guru harus merancang pembelajaran yang efektif di semua pembelajaran tanpa terkecuali dalam membelajarkan IPA.

Menurut Susanto (2013:167) IPA adalah usaha manusia dalam memahami alam semesta melalui pengamatan yang tepat pada sasaran, serta menggunkan prosedur, dan dijelaskan dengan penalaranpenalaran sehingga mendapatkan suatu kesimpulan. Menurut Wardani (2013) Pembelajaran IPA menekankan pada pemberian pengalaman langsung untuk mengembangkan kompetensi agar menjelajahi dan memahami sekitar secara ilmiah. Dalam membelajarakan IPA kepada peserta didik khususnya pada jenjang sekolah dasar, hendaknya diorientasikan pada aktivitas-aktivitas yang mendukung terjadinya pemahaman terhadap konsep, prinsip, dan prosedur dalam kaitannya dengan konteks kehidupan mereka sehari-hari di luar sekolah, agar pembelajaran yang dilaksanakan dalam membelajarkan IPA lebih mudah dimengerti oleh siswa dan pembelajaran menjadi lebih bermakana (Susiani.dkk, 2013). Hal ini sejalan dengan pendapat Susanto (dalam Yudiari, 2015) yaitu, sains/ IPA tidak semata-mata dapat dibelajarkan dengan menggunakan metode ceramah, karena dalam pembelajaran IPA terjadi by doing science.

Pembelajaran yang bermakna membuat siswa lebih memahami materi yang diajarkan dan siswa tidak mudah lupa mengenai apa yang sudah diajarkan. Menurut Shihwenedar (2014) Rustaman dalam Zubaedi (2012: 293) menjelaskan bahwa tujuan pembelajaran IPA ditujukan untuk: 1) meningkatkan kesadaran dan kelestarian lingkungan, kebanggaan nasional, dan kebesaran serta kekuasaan Tuhan Yang Maha Esa; 2) mengembangkan daya penalaran untuk memecahkan masalah sehari-hari; 3) mengembangkan keterampilan proses untuk memperoleh konsep-konsep IPA dan menumbuhkan nilai serta sikap ilmiah; 4) menerapkan konsep dan prinsip IPA untuk menghasilkan karya teknologi sederhana yang berkaitan dengan kebutuhan manusia.

Berdasarkan hasil observasi terhadap guru kelas IV SD Gugus Ir. Soekarno Denpasar Selatan, seluruh guru kelas IV membelajarkan IPA dengan pembelajaran konvensional. Walaupun menggunakan pembelajaran konvensional dalam membelajarakan IPA, hasil belajar IPA siswa relatif baik yakni di atas rata-rata. Namun, masih ada beberapa siswa yang nilainya tepat dengan nilai rata-rata yang diteteapkan sekolah. Untuk mening- katkan hasil belajar IPA siswa diperlukan suatu inovasi pembelajaran yakni pembela- jaran yang efektif dan sesuai dengan pembelajaran IPA, yang tentunya memberikan pengaruh terhadap hasil belajar IPA siswa. Inovasi pembelajaran yang diujicobakan pada penelitian ini adalah model pembelajaran Somatic, Auditory, Visualization dan Intellectualy (SAVI) berbantuan lingkungan hidup. Fitriyani (2015) menyatakan Model pembelajaran SAVI mengarahkan siswa untuk tidak dengan mudah menerima begitu saja pengetahuan hanya karena selama ini memang begitulah caranya, dan mereka tidak akan menganggap suatu buah pikiran itu benar hanya karena gurunya membenarkannya..

Milawati (2011) Kata "Somatis" berasal dari bahasa Yunani yang berarti tubuh. Belajar somatis berarti belajar dengan memanfaatkan indra peraba, kinestetik, praktis melibatkan fisik dan menggerakkan tubuh sewaktu belajar. Dave Meier (dalam Rusman, 2014:373) dinyatakan bahwa model SAVI, adalah kepanjangan dari Somatis, Auditori, Visual dan Intelektual. Somatis artinya belajar dengan bergerak dan berbuat. Auditori, belajar dengan berbicara dan mendengar. Visual, artinya belajar mengamati dan menggambar. Intelektual, artinya belajar dengan memecahkan masalah dan menerangkan. Ngalimun (2016:234) menjelaskan pembelajaran SAVI adalah pembelajaran yang menekankan bahwa belajar haruslah memanfaatkan semua alat indra yang dimiliki siswa. Menurut Astuti (2013) Model pembelajaran SAVI adalah penggunaan cara belajar yang dapat mengoptimalkan fungsi kerja otak dalam memperoleh dan mengkonstruksi pengalaman menjadi suatu pengetahuan dan keterampilan serta sikapsikap yang diperlukan dalam mengkonstruksi pengetahuan tersebut. Cara-cara belajar yang dimaksud, yaitu somatis berarti belajar dengan bergerak dan berbuat, auditori yaitu belajar dengan berbicara dan mendengar, visual yaitu belajar dengan melihat sesuatu, dan intelektual yaitu belajar dengan merenung dan memecahkan masalah.

Istilah SAVI sendiri adalah kependekan dari Somatic yang bermakna gerakan tubuh (Hand-on, aktivitas fisik) belajar dengan mengalami dan melakukan. Auditory yang bermakna bahwa belajar haruslah dengan melalui mendengarkan, menyimak, berbicara, presentasi, argumentasi, mengemukakan pendapat, dan menanggapi. Visualitazion yang bermakna belajar haruslah menggunakan indra mata melalui pengamatan, menggambar, mendemonstrasikan, membaca, mengguankan media dan alat peraga. 
Intellectualy yang bermakna bahwa belajar haruslah menggunakan kemampuan berpikir (minds-on) belajar haruslah dengan kosentrasi pikiran dan berlatih menggunakanannya melalui bernalar, menyelidiki, mengidentifikasi, menemukan, mencipta, mengkonstruksi, memcahkan masalah dan menerapkan. Dari kedua pendapat tersebut dapat disimpulkan bahwa model pembelajaran SAVI adalah model pembelajaran yang memanfaatkan atau melibatkan kelima indra dan emosi dalam proses pembelajaran. Kepanjangan dari SAVI ialah Somatic, Auditory, Visualization dan Intellectualy. Menurut Mariya (2013) Somatic didefinisiskan sebagai learning by moving and doing (belajar dengan bergerak dan berbuat). Auditory adalah learning by talking and hearing (belajar dengan berbicara dan mendengarkan). Visual diartikan learning by observing and picturing (belajar dengan mengamati dan menggambarkan). Intellectual maksudnya adalah learning by problem solving and reflecting (belajar dengan pemecahan masalah dan melakukan refleksi)."

Menurut Shoimin (dalam Mahendra, 2016), model pembelajaran SAVI sangat cocok digunakan dalam pembelajaran IPA karena alasan berikut. 1) Dapat membangkitkan kecerdasan terpadu siswa secara penuh melalui penggabungan gerakan fisik dengan aktifitas intelektual, 2) Memunculkan suasana belajar yang menarik, efektif, dan inovatif, 3) Mampu membangkitkan kreatifitas dan meningkatkan psikomotor siswa, 3) Memaksimalkan ketajaman konsentrasi siswa melalui pembelajaran visual. Dengan $S A V I$, dapat menciptakan suasana belajar menjadi aktif dan menyenangkan. Hal ini akan berdampak pada hasil belajar IPA yang lebih baik.

Pembelajaran SAVI menganut aliran ilmu kognitif modern yang menyatakan belajar yang paling baik adalah melibatkan emosi, seluruh tubuh, semua indera, dan segenap kedalaman serta keluasan pribadi, menghormati gaya belajar individu lain dengan menyadari bahwa orang belajar dengan cara-cara yang berbeda. Mengkaitkan sesuatu dengan hakikat realitas yang nonlinear, nonmekanis, kreatif dan hidup (Herdian 2014). Model pembelajaran SAVI memiliki langkah-langkah atau tahapan-tahapan yang mempermudah dalam penerapan model pembelajaran tersebut. Rusman (2014:373-374) menyatakan model pem- belajaran SAVI ini dilaksankan dalam siklus pembelajaran yang terdiri dari empat tahap a) tahapan persiapan. Harumianiati (2016) menyatakan tujuan tahapan persiapan adalah menimbulkan minat para pembelajar, memberi mereka perasaan positif mengenai pengalaman belajar yang akan datang, dan menempatkan mereka dalam situasi optimal untuk belajar. b) Tahapan penyampaian, tujuan tahap penyampaian adalah membantu pembelajar menemukan materi belajar yang baru dengan cara yang menarik, menyenangkan, relevan, melibatkan panca indra dan cocok untuk semua gaya belajar. c) Tahapan pelatihan, tujuan tahapan pelatihan adalah membantu pembelajar mengintegrasikan dan menyerap pengetahuan dan keterampilan baru dengan berbagai cara. d) Tahapan penampilan hasil. tujuan tahapan penampilan hasil adalah membuat pembelajar menerapkan dan memperluas pengetahuan atau keterampilan baru mereka pada pekerjaan, sehingga hasil belajar melekat dan terus meningkat. Sarnoko.dkk (2016:1236) menjelaskan kelebihan model pembelajaran SAVI adalah a) membangkitkan kecerdasan terpadu siswa secara penuh melalui penggabungan gerak fisik dengan aktivitas intelektual yang membuat pembelajaran menjadi lebih bermakana, b) memunculkan suasana belajar yang lebih baik, menarik dan efektif, c) mampu membangkitkan kreativitas dan meningkatkan kemampuan psikomotor siswa, d) memak- simalkan ketajaman konsentrasi siswa melalui pembelajaran secara visual, auditori dan intelektual, e) Pembelajaran lebih menarik dengan adanya permainan belajar. f) pendekatan yang ditawarkan tidak kaku tetapi dapat sangat bervariasi tergan- tung pada pokok bahasan, dan pembelajarn itu sendiri, g) dapat menciptakan lingkungan belajar yang positif. Penerapan model pembelajaran tersebut lebih maksimal jika melibatkan atau memanfaatkan lingkungan hidup yang ada sebagai sarana belajar. Pembelajaran model SAVI berorientasi keterampilan proses sains sangat mengutamakan aktivitas dan peran siswa dalam belajar (Kusmayuda, 2013).

Sarnoko (2016) menyatakan kelebihan model SAVI antara lain (a) membangkitkan kecerdasan terpadu siswa secara penuh melalui penggabungan gerak fisik dengan aktivitas intelektual, (b) memunculkan suasana belajar yang lebih baik, menarik dan efektif, c) mampu membangkitkan kreativitas dan meningkatkan kemampuan psikomotor siswa, (d) memaksimalkan ketajaman konsentrasi siswa melalui pembelajaran secara visual, auditori dan intelektual, (e) pembelajaran lebih menarik dengan adanya permainan belajar, (f) pendekatan yang ditawarkan tidak kaku tetapi dapat sangat bervariasi tergantung pada pokok bahasan, dan pembelajarn itu sendiri, dan (g) dapat menciptakan lingkungan belajar yang positif.

Menurut Sudjoko.dkk (2008:1.15) lingkungan hidup adalah kesatuan ruang dengan semua benda, daya, keadaan dan makhluk hidup, termasuk manusia dan perilakunya, yang mempengaruhi kelangsungan perikehidupan dan kesejahtraan manusia serta makhluk hidup lainnya. Contoh pembelajaran berbantuan lingkungan hidup yang ada di lingkungan sekolah seperti taman, kelas, laboratorium, kolam, dan benda-benda di sekitar sekolah yang sangat efektif dimanfaatkan pada proses pembelajaran. Lingkungan hidup merupakan salah satu sarana belajar yang kaya dan menarik untuk anak-anak. Guru 
dapat mengembangkan proses pembelajaran, dimana mengajak siswa untuk menggunakan lingkungan hidup yang ada di sekolah sebagai sarana belajar. Namun jika guru menceritakan pembelajaran di dalam ruangan kelas saja tanpa adanya sebuah aktivitas yang melibatkan siswa dalam proses pembelajaran, dampak yang terjadi didalam kelas tidak sealamiah seperti halnya jika guru mengajak anak untuk menggunakan lingkungan hidup sebagai sarana belajar (Dewi.dkk, 2013).

Pemanfaatan lingkungan hidup sebagaisarana belajar ini semakin mem- perkaya wawasan dan pengetahuan anak karena mereka belajar tidak terbatas oleh empat dinding kelas. Selain itu kebenarannya lebih akurat, sebab anak dapat mengalami secara langsung dan dapat mengoptimalkan potensi panca inderanya (Rosyidi.dkk, 2013). Hariyadi.dkk (2016) pemanfaatan lingkungan hidup sebagai sarana belajar memiliki beberapa keuntu- ngan, 1) lingkungan hidup yang ada di sekolah menyediakan berbagai hal yang dapat dipelajari siswa, 2) kegiatan pembel- ajaran lebih menarik dan menyenangkan, 3) proses pembelajaran lebih bermakna, 4) aktivitas siswa lebih meningkat, 5) terjadi pembentukan pribadi siswa.

Pemanfaaatan lingkungan hidup sebagai sarana belajar dapat membuat pembela- jaran menjadi lebih bermakna. Kebermaknaan belajar diperoleh karena adanaya hubungan antara aspek-aspek, konsepkonsep, informasi atau situasi baru dengan komponen-komponen yang relevan di dalam struktur kognitif siswa. Melalui hal tersebut terbentuklah pemahaman yang utuh dimana pengetahuan yang di dapat siswa tidak mudah hilang (Putri.dkk, 2015). Dengan terciptanya pembelajaran yang bermakna maka akan berpengaruh pada meningkatnya hasil belajar IPA siswa.

Hasil belajar IPA adalah suatu hasil yang di peroleh melalui sebuah tes baik itu tes mapun nontes dalam pembelajaran IPA, hasil tersebut menggambarkan sebe- rapa jauh potensi kognitif masing-masing siswa dalam pembelajara IPA. Jika pembelajaran IPA yang dilakukan cenderung monoton, monoton dalam artianya pembelajaran yang dilaksanakan tidak menggunakan model, metode, pendekatan secara bervariasi maka siswa mudah bosan, mengantuk, bahkan selalu ingin keluar ruangan saat mengikuti pembelajaran. Dampak yang ditimbulkan da-ri munculnya sikap tersebut adalah rendahnya hasil belajar IPA sehingga pencapaian tujuan esensial pendidikan IPA mengalami kegagalan (Sudarma.dkk, 2014). Pembe- lajaran monoton identik dengan pembela- jaran yang sering dilakukan di sekolah tersebut, yang biasanya sering disebut dengan pembelajaran konvensional. Menurut Wahyuni.dkk (2014:4) pembelajaran konvensional adalah suatu pende- katan pembelajaran yang secara umum atau pembelajaran yang sering dilakukan oleh kebanyakan guru dalam kegiatan pembelajaran. Pembelajaran yang secara umum atau yang sering digunakan oleh guru kelas IV di SD Gugus Ir. Soekarno Denpasar Selatan dalam kegiatan pembelajaran adalah pembelajaran dengan menggunakan pendekatan saintifik.

Daryanto (2014:51) menyatakan pendekatan saintifik adalah proses pembelajaran yang di rancang sedemikian rupa agar peserta didik secara aktif mengkonstruksi konsep, hukum atau prinsip melalui tahapan-tahapan mengamati (untuk mengidentifikasi atau menemukan masa- lah), merumuskan masalah, mengajukan atau merumuskan hipotesis, mengumpul- kan data dengan berbagai teknik, menga- nalisis data, menarik kesimpulan dan mengkomunikasikan konsep, hukum atau prinsip yang di "temukan". Penerapan pendekaan saintifik dalam pembelajaran melibatkan keterampilan proses seperti mengamati, mengklasifika, mengukur, meramalkan, menjelaskan dan menyimpulkan. Pendekatan saintifik memiliki lima langkah-langkah dalam pembelajaran yaitu: mengamati, menanya, menalar, me- ngasosiasikan, dan mengkomunikasikan.

Berdasarkan uraian di atas, dilakukanlah penilitan yang berjudul Pengaruh Model Pembelajaran SAVI Berban- tuan Lingkungan Hidup terhadap Hasil Belajar IPA Siswa Kelas IV SD Gugus Ir. Soekarno Denpasar Selatan. Tujuan yang ingin dicapai dalam penelitian ini adalah untuk mengetahui apakah terdapat perbedaan yang signifikan terhadap hasil belajar IPA antara siswa kelas IV SD Gugus Ir. Soekarno Denpasar Selatan tahun pelajaran 2016/2017 yang dibelajarkan dengan menggunakan model pembelajaran SAVI berbantuan lingkungan hidup dan siswa kelas IV SD Gugus Ir. Soekarno Denpasar Selatan tahun pelajaran 2016/2017 yang dibelajarkan dengan pem- belajaran konvensional.

\section{Metode}

Tempat penelitian pada pelaksa- naan penelitian ini, dilakukan pada kelas IV SD Gugus Ir. Soekarno Denpasar Selatan. Penelitian kelas eksperimen dilaksankan di kelas IV B SD Negeri 5 Pedungan dan penelitian kelas kontrol dilaksanakan di kelas IV B SD Negeri 2 Pedungan. Waktu pelaksanaan pelenitian ini, dilaksanakan pada bulan April sampai dengan bulan Mei pada semester 2 tahun pelajaran 2016/2017. Rancangan penelitian yang diterapkan dalam pelaksanaan penelitian ini ialah penelitian kuantitatif dengan desain eksperimental yaitu quasi eksperiment (eksperimen semu). Disain yang digunakan dalam eksperimen quasi adalah desain Nonequivalent Control Group Desigh. Rancangan ini cukup ideal dan dapat mengontrol semua ancaman terhadap validitas dan semua sumber. Dalam penelitian ini, peneliti memberikan perlakuan langsung kepada sampel penelitian berupa pembelajaran dengan menggunakan 
model pembelajaran SAVI berbantuan lingkungan hidup pada kelas eksperimen dan pembelajaran konvensional pada kelas kontrol. Rancangan penelitian ini hanya memperhitungkan skor post-test saja yang dilakukan pada akhir penelitian atau dengan kata lain tanpa memperhitungkan skor pre-test. Dalam penelitian ini skor pre-test digunakan untuk menguji keseteraan sampel yakni antara kelas eksperimen dengan kelas kontrol.

Prosedur penelitian yang ditempuh dalam pelaksanaan penelitian ini terdiri dari tiga tahapan yakni persiapan, pelaksanaan, dan pengakhiran eksperimen penelitian. Pada tahapan persiapan peneli- tian, kegiatan yang dilakukan ialah a) Melakukan wawancara dengan kepala SD Gugus Ir. Soekarno Denpasar Selatan dan wali kelas IV untuk mengetahui ada atau tidaknya kelas unggulan, b) Menyusun RPP (Rencana Pelaksanaan Pembelajaran) beserta LKS, c) Mempersiapkan pembelajaran yang di terapkan dalam kelas eksperimen yakni model pembelajaran SAVI berbantuan lingkungan hidup, d) Mengkonsultasikan instrumen penelitian pre-test dan post-test bersama wali kelas dan dosen pembimbing, e) Mengkonsultasikan RPP, LKS dan media pembelajaran bersama wali kelas dan dosen pembimbing, f) Mengadakan uji coba instrumen penelitian soal post-test, g) Memberikan pre-test, h) Analisis data pre-test dengan teknik $u j i t$, i) Melakukan pengundian untuk menetukan kelas eksperimen dan kelas kontrol.

Dalam tahap pelaksanaan penelitian, kegiatan yang dilakukan adalah a) Memberikan perlakuan pada kelas eksperi- men berupa model pembelajaran SAVI berbantuan lingkungan hidup, b) Memberikan perlakuankepada kelas kontrol berupa pembelajaran konvensial, c) Perlakuan yang diberikan terhadap kelas eksperimen dan kelas kontrol adalah sebanyak 6 kali, d) Memberikan post-test pada akhir penelitian, baik untuk kelas eksperimen maupun kontrol untuk mengetahui hasil belajar IPA setelah di berikan perlakuan. Dalam tahap akhir penelitian, kegiatan yang dilakukan, a) Menganalisis data hasil penelitian, b) Melakukan uji hipotesis dan menarik kesimpulan berdasarkan uji hipotesis.

Suatu penelitian tidak luput dari subjek yang diteliti. Subjek tersebut biasanya disebut dengan populasi dan sampel, dimana populasi dan sampel tersebut saling keterkatikan dalam suatu penelitian. Sugiyono (2012:61) menjelaskan populasi adalah wilayah generalisasi yang terdiri atas obyek/ subyek yang mempunyai kualitas dan karakteristik tertentu yang ditetapkan oleh peneliti untuk dipelajari dan kemudian ditarik kesimpulanya. Menurut Dewi (2013) Populasi adalah totalitas semua nilai yang mungkin, hasil menghitung maupun pengukuran, kuantitatif maupun kualitatif dengan karakteristik tertentu mengenai sekumpulan objek yang lengkap dan jelas Jadi dapat disimpulkan bahwa populasi adalah keseluruhan obyek dengan ciri yang sama yang ditetapkan oleh peneliti untuk dipelajari dan kemudian ditarik kesimpulannya. Populasi merupakan keseluruhan dari objek, orang, peristiwa atau sejenisnya yang menjadi perhatian dan kajian dalam penelitian (Setyosari, 2013:221). Dari ke dua pendapat sebelumnya dapat disimpul- kan bahwa populasi adalah kumpulan atau keseluruhan objek dari yang ingin diteliti oleh peneliti lalu dipelajari dan ditarik kesimpulannya. Populasi dari penelitian ini adalah seluruh siswa kelas IV SD Gugus Ir. Soekarno Denpasar Selatan tahun pelajaran 2016/2017 yang berjumlah 329 siswa.

Setelah mengetahui populasi, langkah selanjutnya menetapkan sampel penelitian yang digunakan dalam pelaksa- nan penelitian ini. Sampel adalah suatu kelompok yang lebih kecil atau bagian dari poulasi secara keseluruhan (Setyosari, 2013:221). Sampel adalah bagian dari jumlah dan karakteristik yang dimiliki oleh populasi tersebut (Sugiyono, 2012:81). Dari kedua pendapat tersebut dapat disimpulkan bahwa sampel adalah suatu kelompok kecil yang merupakan bagian dari suatu perkumpulan. Dari pelaksanaan penelitian ini, sampel yang dipergunakan adalah dua kelas. Teknik pengambilan sampel pada penelitian ini adalah Random Sampling. Random sampling merupakan pengambilan sampel secara acak sehingga setiap kelas mendapatkan peluang yang sama untuk menjadi sampel penelitian (Wati, 2014). Setelah dilakukan random, terdapat dua kelas yang dijadikan sampel yakni kelas IV B SD Negeri 2 Pedungan dan kelas IV B SD Negeri 5 Pedungan. Dua kelas tersebut diberikan pretest. Langkah selanjutnya adalah uji kesetaraan kelas, nilai atau skor dari hasil pre-test dianalisis menggunakan uji-t. Sebelum uji kesetaraan menggunakan uji-t, maka data hasil pre-test diuji prasyarat yaitu normalitas dan homogenitasnya. Jika data pre-test yang diperoleh sudah memenuhi prasyarat uji normalitas dan homogenitas maka dianalisi menggunakan uji t. Setelah kedua kelas diketahui setara secara akademik, langkah selajutnya ialah melakukan pengundian untuk menentukan kelas yang digunakan sebagai kelas kontrol dan kelas eksperimen. Sehingga di tetapkanlah sampel yang digunakan dalam penelitian ini adalah kelas IV B SD Negeri 5 Pedungan sebagai kelas eksperiem yang berjumlah 37 siswa dan kelas IV B SD Negeri 2 Pedungan sebagai kelas kontrol yang berjumlah 39 siswa.

Variabel yang digunakan dalam penelitian ini ada 2 yaitu variable bebas dan variable terikat. Variabel bebas adalah variabel yang menyebabkan atau mempe- ngaruhi, yaitu faktor-faktor yang diukur, dimanipulasi, atau dipilih untuk peneliti untuk menentukan hubungan antara fenomena yang diobservasi atau diamati (Setyosari, 2013 :164). Pada penelitian ini yang menjadi variable bebas adalah model pembelajaran SAVI berbantuan lingkungan hidup. Sedangkan variabel terikat adalah faktor-faktor yang di 
observasi dan diukur untuk menentukan adanya pengaruh variabel bebas yaitu faktor yang muncul, atau tidak muncul atau, berubah sesuai dengan yang diperkenalkan oleh peneliti itu (Setyosari, 2013:165). Variabel terikat dalam penelitian ini adalah hasil belajar IPA.

Dalam pengumpulan data, data yang diperlukan dalam penelitian ini adalah data tentang hasil belajar IPA. Metode yang digunakan untuk mengumpulkan data tersebut adalah dengan menggunakan motode tes. Arifin (2012:3) menjelaskan tes adalah suatu alat yang berisi serangkaian tugas yang harus dikerjakan atau soal-soal yang harus dijawab oleh peserta didik untuk mengukur suatu aspek prilaku tertentu. Menurut Atmaja (2017) Sebelum tes diberikan kepada siswa maka dilakukan pengujian istrumen penelitian untuk mendapatkan gambaran kelayakan instrumen yang digunakan sebagai instrument penelitian. Agar memenuhi persyaratan instrumen yang baik, instrumen tersebut perlu dianalisismenggunakan ujivaliditas dan reabilitas. Uji validitas instrumen dilakukan dengan uji validitas isi (Judgment expert).

Yusuf (2015:93) menyatakan tes adalah suatu prosedur yang spesifik dan sistematis untuk mengukur tingkah laku seseorang. Dari beberapa pendapat tersebut, dapat di simpulkan tes adalah suatu alat atau instrument yang digunakan untuk mengukur kemampuan peserta didik dalam sapek tertentu. Tes yang digunakan untuk mengukur hasil belajar IPA berupa tes objektif dalam bentuk pilihan ganda biasa. Data yang dianalisis dalam penelitian ini adalah data tes hasil belajar IPA setelah diberikan perlakuan.

\section{Hasil dan Pembahasan}

Data yang dianalisis pada penelitian ini adalah data hasil belajar IPA siswa Kelas IV tema 9 Kayana Negeriku pada kelas eksperimen dan kelas kontrol. Data hasil belajar IPA didapat atau diperoleh hasil post-test yang telah diberikan pada akhir penelitian. Sebelum dilakukan pengujian hipotesis, terlebih dahulu dilakukan uji prasyarat yang meliputi uji normalitas dan uji homogenitas. Uji normalitas data dilaku- kan pada dua kelompok data, meliputi data siswa yang dibelajarkan dengan model pembelajaran SAVI berbantuan lingkungan hidup dan data siswa yang dibelajarkan dengan pembelajaran konvensional. Uji ini dilakukan untuk mengetahui sebaran data nilai hasil belajar IPA yang digunakan dalam pengujian hipotesis berdistribusi normal atau tidak. Uji normalitas sebaran data dilakukan dengan menggunakan uji Chi Square $\left(X^{2}\right)$. Berdasarkan analisis uji Chi Square $\left(X^{2}\right)$ pada sebaran data kelas eksperimen, dipreoleh hasil $X^{2}$ hitung $=4,79$ dan sedangkan untuk taraf signifikansi $5 \%(\alpha=0,05)$ dan derajat kebebasan $(\mathrm{dk})=5$ diperoleh $\mathrm{X}^{2}$ tabel $=11,07$. Dengan demikian hasil $\mathrm{X}^{2}$ hitung $<\mathrm{X}^{2}$ tabel ini berarti data hasil belajar IPA pada kelas eksperimen berdistribusi normal. Sedangkan analisis uji Chi Square $\left(X^{2}\right)$ pada sebaran data kelas kontrol, dipreoleh hasil $X^{2}$ hitung $=2,45$ dan sedangkan untuk taraf signifikansi $5 \%(\alpha=0,05)$ dan derajat kebebasan $(\mathrm{dk})=5$ diperoleh $\mathrm{X}^{2}$ tabel $=11,07$. Dengan demikian hasil $\mathrm{X}^{2}$ hitung $<\mathrm{X}^{2}$ tabel ini berarti data hasil belajar IPA pada kelas kontrol berdistribusi normal. Setelah diketahuin kedua data tersebut berdistribusi normal langkah selajutnya adalah melakukan uji homogenitas.

Uji homogenitas varian ini dilakukan berdasarkan data hasil belajar IPA siswa yang dibelajarkan dengan model pembe- lajaran SAVI berbantuan lingkungan hidup dan data siswa yang di belajarkan dengan pembelajaran konvensional. Jumlah masing-masing siswa pada analisis adalah 37 untuk kelas eksperimen dan 39 untuk kelas kontrol.Untuk menentukan homogenitas variannya menggunakan uji $\mathrm{F}$. Berdasarkan hasil perhitungan uji $\mathrm{F}$ diperoleh Fhitung1,28 dan pada taraf signifikan 5\% dengan derajat kebebasan untuk pembi- lang $\mathrm{n}_{1}-1 \quad(37-1=36)$ dan derajat kebebasan untuk penyebut $\mathrm{n}_{2}-1 \quad(39-1=38)$ diperoleh nilai $F_{\text {tabel }}=1,71$. Dengan demikian $F_{\text {hitung }}<F_{\text {tabel }}$ ini berarti kedua data tersebut homogen. uji prasyarat yang meliputi uji normalitas dan uji homogenitas yang telah dilakukan dapat disimpulkan bahwa data hasil belajar IPA siswa berdistribusi normal dan homogen. Berdasarkan hasil uji normalitas dan uji homogenitas varians diperoleh data kedua kelompok yaitu siswa yang di belajarkan dengan model pembe- lajaran SAVI berbantuan lingkungan hidup dan siswa yang dibelajarkan dengan pembelajaran konvensional berdistribusi normal dan varian kedua kelompok homo- gen,maka langkah selanjutnya melakukan uji hipotesis menggunakan uji-t. Dengan kriteria pengujian jika $t_{\text {hitung }}<\mathrm{t}_{\text {tabel, }}$ maka $\mathrm{H}_{0}$ diterimadan $\mathrm{H}_{\mathrm{a}}$ ditolak, dan jika harga thitung $>\mathrm{t}_{\text {tabel }}$, maka $\mathrm{H}_{0}$ ditolak dan $\mathrm{H}_{\mathrm{a}}$ diterima. Pada taraf signifikansi $5 \%(\alpha=0,05)$ dengan derajat kebebasan $(\mathrm{dk}=37+39-2=74)$ diperoleh nilai $\mathrm{t}_{\text {tabel }}=2,00$. Hasil perhitungan uji hipotesis disajikan dalam tabel berikut.

Tabel 1. Tabel Uji Hipotesis Penelitian Kelas Eksperimen dan Kelas Kontrol

\begin{tabular}{cccc}
\hline Kelompok Penelitian & thitung & tabel & Kesimpulan \\
\hline $\begin{array}{c}\text { Hasil belajar IPA kelas eksperimen } \\
\text { dan kelas kontrol }\end{array}$ & 3,49 & 2.00 & $\mathrm{H}_{0}$ (Ditolak) \\
\hline
\end{tabular}


Berdasarkan tabel di atas, diperoleh thitung $=3,49$ sedangkan pada taraf signifikansi $5 \%$ dengan $\mathrm{dk}=$ 74 diperoleh nilai tabel $=2,00$ sehingga thitung $=3,49>$ tabel $=2,00$. Dapat dilihat bahwa $t_{\text {hitung }}>t_{\text {tabel }}$ yaitu $3,49>2,00$. Dengan hasil tersebut maka dapat disimpulkan bahwa $\mathrm{H}_{0}$ yang berbunyi "tidak terdapat perbedaan yang signifikan terhadap hasil belajar IPA antara siswa kelas IV SD Gugus Ir. Soekarno Denpasar Selatan tahun pelajaran2016/2017 yang dibelajarkan dengan menggunakan model pembelajaran SAVI berbantuan lingkungan hidup dan siswa kelas IV SD Gugus Ir. Soekarno Denpasar Selatan tahun pelajaran 2016/2017 yang dibelajarkan dengan pembelajaran konvensioanl", ditolak dan $\mathrm{H}_{\mathrm{a}}$ yang menyatakan "terdapat perbedaan yang signifikan terhadap hasil belajar IPA antara siswa kelas IV SD Gugus Ir. Soekarno Denpasar Selatan tahun pelajaran 2016/2017 yang dibelajarkan dengan menggunakan model pembelajaran SAVI berbantuan lingkungan hidup dan siswa kelas IV SD Gugus Ir. Soekarno Denpasar Selatan tahun pelajaran 2016/2017 yang dibelajarkan dengan pembelajaran konvensioanl", diterima. Dengan demikian, terdapat pengaruh hasil belajar IPA antara siswa yang di belajarkan dengan model pembelajaran SAVI berbantuan lingkungan hidup dan siswa yang di belajarkan dengan pembelajaran konvensional pada siswa kelas IV SD Gugus Ir. Soekarno Denpasar Selatan tahun pelajaran 2016/2017.

\section{Simpulan dan Saran}

Berdasarkan penelitian yang telah dilaksanakan maka dapat ditarik simpulan sebagai berikut: a) hasil belajar IPA siswa yang dibelajarkan dengan model pembe- lajaran SAVI berbantuan lingkungan hidup pada kelas eksperimen nilai rata-rata siswa sebesar 74,05 yakni dengan nilai tertinggi yang diperoleh siswa adalah 88 dan nilai terendah 60 . b) hasil belajar IPA siswa yang dibelajarkan dengan pembela- jaran konvensional pada kelas kontrol nilai rata-rata siswa sebesar 67,48 dengan nilai tertinggi yang diperoleh siswa adalah 82 dan nilai terendah 50. c) rata-rata hasil belajar IPA siswa yang di belajarkan dengan model pembelajaran SAVI berban- tuan lingkungan hidup lebih tinggi dari pada siswa yang dibelajarkan dengan pembe- lajaran konvensional $(75,05>68,48)$. Berdasarkan hasil analisis dengan meng- gunakan uji-t diperoleh thitung $=3,49$ sedang- kan pada taraf signifikansi $5 \%$ dengan $\mathrm{dk}=74$ diperoleh nilai $t_{\text {tabel }}=2,00$ sehingga $t_{\text {hitnung }}=3,49>t_{\text {tabel }}=2,00$.

Dengan demikian, hipotesis nol $\left(\mathrm{H}_{0}\right)$ ditolak yang berbunyi "tidak terdapat perbedaan yang signifikan terhadap hasil belajar IPA antara siswa kelas IV SD Gugus Ir. Soekarno Denpasar tahun pelajaran Selatan 2016/2017 yang dibelajarkan dengan menggunakan model pembelajaran SAVI berbantuan lingkungan hidup dan siswa kelas IV SD Gugus Ir. Soekarno Denpasar Selatan tahun pelajaran 2016/2017 yang dibelajarkan dengan pembelajaran konvensioanl". Dengan demikian dikatakan bahwa tidak terdapat perbedaan yang signifikan terhadap hasil belajar IPA antara siswa kelas IV SD Gugus Ir. Soekarno Denpasar tahun pelajaran Selatan 2016/2017 yang dibelajarkan dengan menggunakan model pembelajaran SAVI berbantuan lingkungan hidup dan siswa kelas IV SD Gugus Ir. Soekarno Denpasar Selatan tahun pelajaran 2016/2017 yang dibelajarkan dengan pembelajaran konvensional.

Berdasarkan hasil penelitian, pembahasan dan simpulan, maka dapat dia- jukan beberapa saran kepada beberapa pihak sebagai berikut: a) Kepada guru, Penerapan model pembelajaran dalam penelitian ini dapat menambah wawasan guru mengenai inovasi pembelajaran dalam meningkatkan hasil belajar siswa khususnya dalam pembelajaran IPA. b) Kepada siswa, Melalui penelitian ini, pem- belajaran dengan terlibatnya siswa dalam proses pembelajaran terus diterapkan dan ditingkatkan lagi agar proses pembelajaran menjadi lebih bermakna, kebermaknaan tersebut membuat pengetahuan yang di dapatan susah hilang dan tentunya melalui pembelajaran yang bermakna hasil belajar siswa terus meningkat. c) Kepada sekolah, Melalui penelitian ini dapat menjadi masukan dalam mengembangkan proses pembelajaran di kelas dan dengan berkembangan proses pembelajaran di kelas dapat meningkatkan prestasi sekolah nantinya. d) Kepada peneliti lainnya, penelitian ini dapat memberikan refrensi terhadap peneliti lain mengenai bagaimana proses pelaksanaan penelitian serta menambah wawasan peneliti dalam mengatasi permasalahan yang ada di lapangan dalam pelaksanaan penelitian yakni menggunakan model pembelajaran SAVI berbantuan lingkungan hidup khususnya dalam pem- belajaran IPA.

\section{Daftar Rujukan}

Arifin, Zainal. 2010. Evaluasi Pembela- jaran. Cetakan kedua. Bandung. PT. Remaja Rosdakarya Offset.

Daryanto. 2014. Pendekatan Pembelajaran Saintifik Kurikulum 2013. Yogyakar- ta: Gava Media. 
Dewi, Kadek Herry Puspa. dkk. 2013. "Pengaruh Model Pembelajaran Resolusi Konflik Berbantuan Media Lingkungan Terhadap Sikap Multikultur dan Prestasi Belajar IPS". e-Journal Program Pasca- sarjana Universitas Pendidikan Ganesha Jurusan Pendidikan Dasar, Volume 3, (hlm.3).

Hariyadi, Dedy. dkk. 2016. “Pengaruh Model Pembelajaran Inkuiri Ter- bimbing Berbasis Lingkungan Terhadap Keterampilan Proses dan Penguasaan Konsep IPA Siswa Kelas VII SMP Negeri 4 Kopang pada Materi Ekosistem". Jurnal Pendidikan, Volume 1, Nomor 8 (hlm.1569).

Haruminati, N. W. Y., Suarni, N. K., \& Sudarma, I. K. (2016). Pengaruh Model Pembelajaran Savi Terhadap Minat Belajar Matematika Siswa Kelas IV SD Mutiara Singaraja. Mimbar Pgsd, 4(1), 1-11. Retrieved From Https://Ejournal.Undiksha.Ac.Id/Index.Php/JJPGSD/Article/View/6982.

Jasdilla. 2017. Hasil Belajar dan Pembelajaran Kooperatif Tipe TPS. Jurnal Pendidikan Indonesia Vol. 6, No.1, April 2017.

Mariya, D., Mastur, Z., \& Pujiastuti, E. (2013). Keefektifan Pembelajaran Savi Berbantuan Alat Peraga Terhadap Kemampuan Pemecahan Masalah Info Artikel Abstra. Unnes Journal Of Mathematics Education, 2(2).

Ngalimun. 2016. Strategi Dan Model Pem- belajaran. Yogyakarta: Aswaja Pre- ssindo.

Putri, Ni Made Sukirtayanti Ari. dkk. 2015. "Pengaruh Implementasi Pembela jaran Tematik Berbasis Lingkungan Terhadap Hasil Belajar IPA Ditinjau dari Sikap Ilmiah Siswa Kelas IV SD Gugus I Kecamatan Kuta". e-Journal Program Pascasarjana Universitas Pendidikan Ganesha Program Studi Pendidikan Dasar, Volume 5, (hlm.2).

Parinduri, S. H., Sirait, M., \& Sani, R. A. (2017). The Effect of Cooperative Learning Model Type Group Investigation for Student â€ $€^{\mathrm{TM}}$ s Conceptual Knowledge and Science Process Skills, 7(October), 4954. https://doi.org/10.9790/7388-0704034954

Putu, P., Dewi, Y., Manuaba, I. B. S., \& Suniasih, N. W. (2017). Pengaruh Model Pembelajaran Group Investigation Berbasis Proyek Terhadap Hasil Belajar Ipa Siswa Kelas Iv, 1, 264-271. Retrieved from https://ejournal.undiksha.ac.id/index.php/IJEE/article/view/12957

Rusman. 2014. Model - Model Pembelaja- ran Mengembangkan Profesionalis- me Guru. Jakarta: PT Raja Grafindo Persada.

Rosyidi, Ahyar. dkk. 2013. "Pengaruh Penerapan Model Pembelajaran Quantum Berbasis Lingkungan Terhadap Motivasi Belajar dan Prestasi Belajar IPA Kelas VI SMPN I Keruak Tahun Pembela- jaran 2011/2012". e-Journal Prog- ram Pascasarjana Universitas Pendidikan Ganesha Program Studi Pendidikan Dasar, Volume 3, (hlm.3).

Sarnoko. dkk. 2016. "Penerapan Pendekat- an SAVI Berbantuan Video Pembel- ajaran untuk Meningkatkan Aktivi- tas dan Hasil Belajar IPS Siswa Kelas IV SDN I Sanan Girimarto Wonogiri". Jurnal Pendidikan,Vol- ume 1, Nomor 7 (hlm.1236).

Sihwinedar, R. (1945). Meningkatkan Hasil Belajar Ipa Melalui Penerapan Model Pembelajaran Savi (Somatis, Auditori, Visual, Dan Intelektual) Pada Siswa Kelas Iii Sdn Rejoagung 01 Semboro Tahun Pelajaran 2013/2014.

Setyosari, Punjai. 2013. Metode Penelitian Pendidikan Dan Pengembangan. Jakarta: Prenada Media Group.

Setyosari, P., \& Malang, P. D. P. (2016). Penerapan Pendekatan Savi Berbantuan Video Pembelajaran Untuk Meningkatkan Siswa Kelas Iv Sdn I Sanan, 1235-1241.

Suma, I. K., Suastra, I. W., \& Astika, U. (2013). Pengaruh model pembelajaran berbasis masalah terhadap sikap ilmiah dan keterampilan berpikir kritis. Universitas Pendidikan Ganesha, 3, 1-10.

Sudarma, I Nyoman. dkk. 2014. "Pengaruh Model Pembelajaran Berbasis Masalah terhadap Aktivitas dan Hasil Belajar IPA Siswa Kelas V SD Gugus II Kecamatan Kuta Tahun Pelajaran 2013/2014". e-Journal Program Pascasarjana Universitas Pendidikan Ganesha Program Studi Pendidikan Dasar. Volume 4, (hlm.23).

Sudjoko, dkk. 2008. Pendidikan Lingkung- an Hidup. Universitas Terbuka.

Sugiyono. 2012a. Statistika Untuk Peneliti- an. Bandung: Alfabeta. 
Sugiyono. 2012b. Motode Penelitian Kuantitatif Kualitatif dan R\&D. Bandung: Alfabeta.

Susanto, Ahmad. 2013. Teori Belajar \& Pembelajaran Di Sekolah Dasar. Jakarta: Prenadamedia Group.

Susiani, Ketut. dkk. 2013. "Pengaruh Model Pembelajaran Quantum Terhadap Kecerdasan Sosio Emosional dan Prestasi Belajar IPA Siswa Kelas V SD di Banyuning". e-Journal Program Pascasarjana Universitas Pendidikan Ganesha Jurusan Pendidikan Dasar, Volume 3, (hlm.2).

Teti, M. (2011). Peningkatan Kemampuan Anak Memahami Drama Dan Menulis Teks Drama Melalui Model Pembelajaran Somatis Auditori Visual Intelektual (Savi). Jurnal Upi, Edisi Khus(2), 70-78.

Wahyuni, Desak Putu Diah. dkk. 2014. "Pengaruh Model Pembelajaran Inquiry Terbimbing Terhadap Hasil Belajar Matematika Ditinjau dari Keterampilan Numerik Siswa Kelas V SD Gugus 5 Tampaksiring". e-Journal Program Pascasarjana Universitas Pendidikan Ganesha Program Studi Pendidikan Dasar, Volume 4, (hlm.4).

Wardani, Risna Isnaeni, Ngadino Y, J. D. (2013). Penggunaan Model Pembelajaran Somatic, Auditory, Visualization, And Intellectualy (Savi) Untuk Meningkatkan Pemahaman Konsep Gaya

Yusuf, Muri. 2015. Asesmen Dan Evaluasi Pendidikan. Jakarta: Prenadamedia Group.

Yudiari, Md. Mei, Dsk. Pt. Parmiti, D. N. S. (2015). Pengaruh Model Pembelajaran Saviberbantuan Media Mind Mapping Terhadap Hasil Belajar Ipasiswa Kelas V Universitas Pendidikan Ganesha e-Journal PGSD Universitas Pendidikan Ganesha 